\title{
Keragaman Spesies Tersangka Vektor Filariasis Berdasarkan Tipe Habitat dan Ekosistem di Kabupaten Sarmi Provinsi Papua
}

\author{
The Diversity of Suspected Vector of Lymphatic Filariasis Based on Habitat and Ecosystem \\ Characteristic in Sarmi Regency, Papua Province
}

\author{
Milana Salim¹, Mara Ipa², Olwin Nainggolan ${ }^{3}$ \\ 1 Balai Litbang Kesehatan Baturaja \\ ${ }^{2}$ Loka Litbang Kesehatan Pangandaran \\ ${ }^{3}$ Puslitbang Upaya Kesehatan Masyarakat Badan Litbangkes
}

\begin{abstract}
Filariasis is one of the diseases that require a vector for the transmission process. Information on the determinants of filariasis transmission related to vectors is needed as a basis for control efforts. Further analysis of Vektora Research in 2015 was conducted in order to identify the diversity species of suspected filariasis vector and the environmental characteristics in Sarmi District of Papua Province. Data on mosquito catching, habitat type, and environment each ecosystem analyzed. Filariasis suspect vector species in Sarmi Regency Papua Province obtained were four genus with nine species. These vector/suspect filariasis vector were Anopheles farauti, An. koliensis, An. pediateniatus, An. punctulatus, An. tesselatus, An. subalbatus, Culex quinquefasciatus, Mansonia dives, and Ma. papuensis. Four specific habitat characteristics were found in the mosquito-data collecting sites: primary forest, secondary forest, shrubs, and grass/brown/grassland habitat. Anopheles farauti is a species found abundantly in all specific habitats. Based on the ecosystem, Cx. quinquefasciatus dominates the urban ecosystems of non-forest settlements and beaches near settlements, while An. farauti is found in forests settlements, remote forest settlements, nonremote forest settlements, distant coastal settlements, and beaches near settlements.
\end{abstract}

Keywords: Variation, mosquito density, vectors, habitat characteristics, filariasis

\begin{abstract}
Abstrak. Filariasis masih menjadi masalah kesehatan di Kabupaten Sarmi. Pada tahun 2014 tercatat terdapat 76 kasus baru. Informasi mengenai aspek penentu penularan filariasis dalam hubungannya dengan vektor dibutuhkan sebagai dasar upaya pengendalian. Analisis lanjut Riset Khusus Vektora tahun 2015 dilakukan dengan tujuan untuk mengetahui variasi dan karakteristik lingkungan spesies tersangka vektor filariasis di Kabupaten Sarmi Provinsi Papua. Data penangkapan nyamuk, jenis habitat, dan lingkungan setiap ekosistem dianalisis. Spesies tersangka vektor filariasis di Kabupaten Sarmi Provinsi Papua yang diperoleh terdiri dari empat genus dengan sembilan spesies vektor/tersangka vektor filariasis yaitu Anopheles farauti, An. koliensis, An. pediateniatus, An. punctulatus, An. tesselatus, An. subalbatus, Culex quinquefasciatus, Mansonia dives, dan Ma. papuensis. Ditemukan empat tipe habitat spesifik di lokasi pengumpulan data nyamuk yakni hutan primer, hutan sekunder, semak, dan habitat rumput/sawah/kebun coklat. Anopheles farauti merupakan spesies yang ditemukan melimpah pada semua habitat spesifik. Berdasarkan ekosistem, $C x$. quinquefasciatus mendominasi ekosistem di daerah urban yaitu non hutan dekat pemukiman, hutan dekat pemukiman, dan pantai dekat pemukiman, sedangkan An. farauti ditemukan di lima ekosistem yakni hutan dekat pemukiman, hutan jauh pemukiman, non hutan jauh pemukiman, pantai jauh pemukiman, dan pantai dekat pemukiman.
\end{abstract}

Kata Kunci: Variasi, kepadatan nyamuk, vektor, karakteristik habitat, filariasis

${ }^{1}$ Korespondensi: milanwords@yahoo.co.id | Tel.: +62 85268929917 


\section{PENDAHULUAN}

Limfatik Filariasis diketahui endemis di 73 negara, diperkirakan 1,39 juta orang yang hidup di wilayah endemis menjadi target pengobatan. ${ }^{1}$ Sebagian besar kasus global yang disebabkan Wuchereria bancrofti, Brugia malayi, dan $B$. timori sama pentingnya dengan kasus yang terjadi di kawasan Asia Tenggara yakni yang terdapat di sembilan negara, termasuk Indonesia. ${ }^{2}$ Lima provinsi dengan kasus klinis filariasis tertinggi pada tahun 2015, yaitu Nusa Tenggara Timur (2.864), Aceh (2.372), Papua Barat (1.244), Papua (1.184), dan Jawa Barat (904). Berdasarkan hasil pemetaan daerah endemis di Indonesia diperoleh sebanyak 241 kabupaten/kota merupakan daerah endemis Filariasis. $^{3}$

Filariasis sudah lama menjadi penyakit endemis di Provinsi Papua yang tersebar pada beberapa kabupaten/kota. Sejalan dengan kebijakan nasional tentang program eliminasi filariasis Provinsi Papua telah melakukan Pemberian Obat Massal Pencegahan filariasis (POMP filariasis) selama 5 (lima) tahun berturutturut yang dimulai tahun 2008 s/d tahun 2012. Data laporan kasus filariasis kabupaten/kota di Provinsi Papua sampai dengan tahun 2012 menunjukkan Kabupaten Sarmi memiliki Mf rate tertinggi yaitu 47,06\%. ${ }^{4}$ Berdasarkan data dari Dinas Kesehatan Kabupaten Sarmi disebutkan bahwa kasus baru filariasis di Kabupaten Sarmi ada 76 kasus selama tahun 2014. Hal ini menunjukkan filariasis limfatik masih menjadi masalah kesehatan masyarakat di Kabupaten Sarmi. ${ }^{5}$

Strategi utama adalah pemberian obat/mass drug administration (MDA) dengan kombinasi albendazole-diethylcarbamazine (DEC) pada semua penduduk di wilayah dimana prevalensi Lymphatic Filariasis (LF) $\geq 1 \%$, dan didukung oleh pengendalian vektor untuk mengurangi keterpaparan dengan nyamuk. Limfatik filariasis bersifat unik di antara penyakit tular vektor karena bisa ditularkan oleh spesies nyamuk dari lima genus, yakni Aedes, Anopheles, Culex, Mansonia, dan Ochlerotatus. ${ }^{2}$

Pada tahun 2006 telah dikonfirmasi 23 spesies nyamuk dari genus Mansonia, Anopheles, Culex, Aedes, dan Armigeres yang menjadi vektor filariasis di Indonesia. Sepuluh spesies nyamuk Anopheles telah diidentifikasi sebagai vektor $W$. bancrofti tipe pedesaan. Culex quinquefasciatus merupakan vektor $W$. bancrofti tipe perkotaan. Enam spesies Mansonia merupakan vektor $B$. malayi. Di Indonesia bagian timur, Mansonia dan An. barbirostris merupakan vektor filariasis yang penting. Di Provinsi Papua, spesies vektor untuk W. bancrofti, antara lain An. farauti, An. koliensis,
An. punctulatus, An. bancrofti, $C x$. annulirostris, $C x$. bitaeniorhynchus, Cx. quinquefasciatus, Ae. kochi, Ar. subalbatus, dan Ma. uniformis. ${ }^{6}$ Selain itu $A n$. Peditaeniatus; An. vagus; Armigeres subalbatus; empat spesies Culex yaitu, $C x$. annulirostris, $C x$. bitaeniorhyncus, Cx. Quinquefasciatus, dan $C x$. orchracea; serta enam spesies Mansonia (Ma. annulata, Ma. annulifera, Ma. bonneae, Ma. dives, Ma. Indiana, dan Ma. uniformis) juga merupakan vektor filariasis di Indonesia. ${ }^{7}$

Penelitian ini merupakan analisis lanjut terhadap data hasil survei skala nasional, Riset Khusus Vektor (Rikhus Vektora) tahun 2015 yang dilaksanakan oleh Badan Penelitian dan Pengembangan Kesehatan. Di Provinsi Papua ada tiga kabupaten yang menjadi lokasi pengambilan data Rikhus Vektora yakni Kabupaten Biak Numfor, Kabupaten Merauke, dan Kabupaten Sarmi. Di antara ketiga kabupaten tersebut, Kabupaten Sarmi adalah satu-satunya kabupaten yang masih ditemukan kasus filariasis pada tahun 2014. Informasi mengenai kepadatan vektor di berbagai ekosistem sebagai penentu penularan filariasis di Kabupaten Sarmi masih terbatas sehingga diperlukan analisis lanjut terhadap data yang telah dikumpulkan mengenai hal tersebut. Hal ini penting untuk diketahui agar informasi ini dapat digunakan oleh berbagai pihak, terutama pengelola program dalam rangka mendukung program eliminasi filariasis.

\section{BAHAN DAN METODE}

Metode penelitian Rikhus Vektora dilakukan secara observasional deskriptif menggunakan rancangan studi potong lintang. Kabupaten Sarmi terletak di Pantai Utara Papua pada posisi koordinat $138,05^{\circ}-140,30^{\circ}$ Bujur Timur dan $1,35^{\circ}-3,35^{\circ}$ Lintang Selatan. ${ }^{5}$. Tipe ekosistem untuk penangkapan nyamuk ditetapkan menjadi enam ekosistem, yakni ekosistem hutan dekat pemukiman (HDP), hutan jauh pemukiman (HJP), non hutan dekat pemukiman (NHDP), non hutan jauh pemukiman (NHJP), pantai dekat pemukiman (PDP), dan pantai jauh pemukiman (PJP).

Data nyamuk yang dianalisis merupakan hasil identifikasi spesies dari penangkapan nyamuk dengan berbagai metode. Metode yang digunakan, yakni penangkapan nyamuk saat hinggap pada manusia (umpan orang), penangkapan nyamuk di sekitar kandang ternak, penangkapan nyamuk menggunakan perangkap hewan/animal baited trap-net (ABT), dan penangkapan nyamuk pada pagi hari menggunakan jaring serangga. Waktu penangkapan nyamuk di malam hari selama 12 jam, mulai jam 18.00 sampai dengan jam 06.00 WIT. Untuk penangkapan dengan umpan orang dilakukan 
selama 50 menit per jam di dalam dan di luar rumah dengan jumlah penangkap sebanyak enam orang, sedangkan penangkapan nyamuk dengan umpan ternak dilakukan 15 menit per jam. Waktu penangkapan nyamuk di pagi hari mulai jam 07.00-10.00 WIT. Data nyamuk di Kabupaten Sarmi yang berhasil dikumpulkan meliputi data spesies nyamuk, data faktor lingkungan (suhu, kelembapan, kecepatan angin, dan kondisi cuaca), dan data habitat spesifik. Penangkapan nyamuk per metode dilakukan sebanyak dua kali pada tiap-tiap ekosistem, kecuali penangkapan di pagi hari hanya dilakukan satu kali per ekosistem. Analisis dilakukan secara deskriptif terhadap jumlah spesies nyamuk yang tertangkap dengan berbagai metode penangkapan. Selanjutnya dilakukan analisis korelasi Pearson untuk melihat adanya hubungan antara variabel lingkungan (temperatur dan kelembapan) terhadap jumlah nyamuk tertangkap, dan analisis sidik ragam (ANOVA) untuk melihat pengaruh antara metode penangkapan terhadap nyamuk yang tertangkap. Dilakukan juga perhitungan angka kepadatan nyamuk per jam per penangkap (Man Hour Density) dengan membagi jumlah spesies yang tertangkap dengan angka pembagi yang berupa lama waktu penangkapan per jam
(50/60 menit) dikalikan dengan jumlah jam penangkapan semalam sebanyak dua kali penangkapan, dan jumlah penangkap. Total angka pembagi adalah $120(0,83 \times 12 \times 2 \times 6)$.

Persetujuan etik Rikhus Vektora 2015 diperoleh dari Komisi Etik Penelitian Kesehatan (KEPK) Badan Penelitian dan Pengembangan Kesehatan, Kementerian Kesehatan Republik Indonesia (No. LB.02.01/5.2/KE. 355/2014).

\section{HASIL}

Total jumlah nyamuk tertangkap adalah 3.632 ekor. Hasil penangkapan nyamuk menunjukkan bahwa pada ekosistem NHJP terdapat lebih banyak spesies sebesar 26,6\% dibanding ekosistem lainnya. Jumlah nyamuk yang tertangkap lebih banyak pada ekosistem non hutan, baik yang dekat maupun yang jauh dari pemukiman (Gambar 1).

Hasil penangkapan nyamuk menunjukkan bahwa telah ditemukan 31 spesies dari lima genus nyamuk di Kabupaten Sarmi dengan berbagai metode penangkapan. Genus Aedes merupakan nyamuk yang paling beragam spesiesnya dengan jumlah paling banyak tertangkap (Gambar 2).

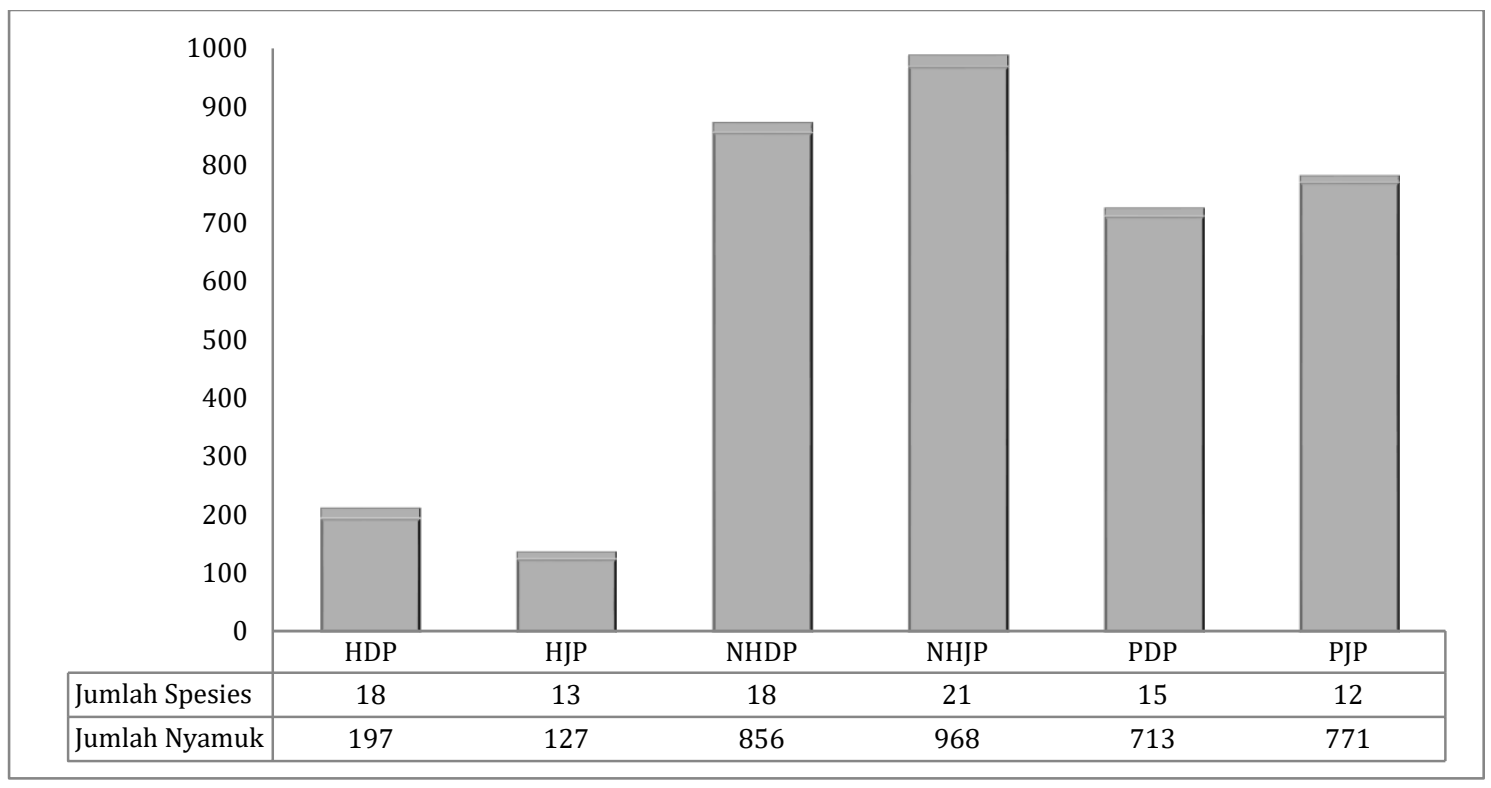

Keterangan: $\mathrm{HDP}=$ hutan dekat pemukiman; HJP = hutan jauh pemukiman; NHDP= non hutan dekat pemukiman; $\mathrm{NHJP}=$ non hutan jauh pemukiman; $\mathrm{PDP}=$ pantai dekat pemukiman; $\mathrm{PJP}=$ pantai jauh pemukiman

Gambar 1. Jumlah Spesies Nyamuk yang Tertangkap di Setiap Ekosistem di Kabupaten Sarmi Tahun 2015. 


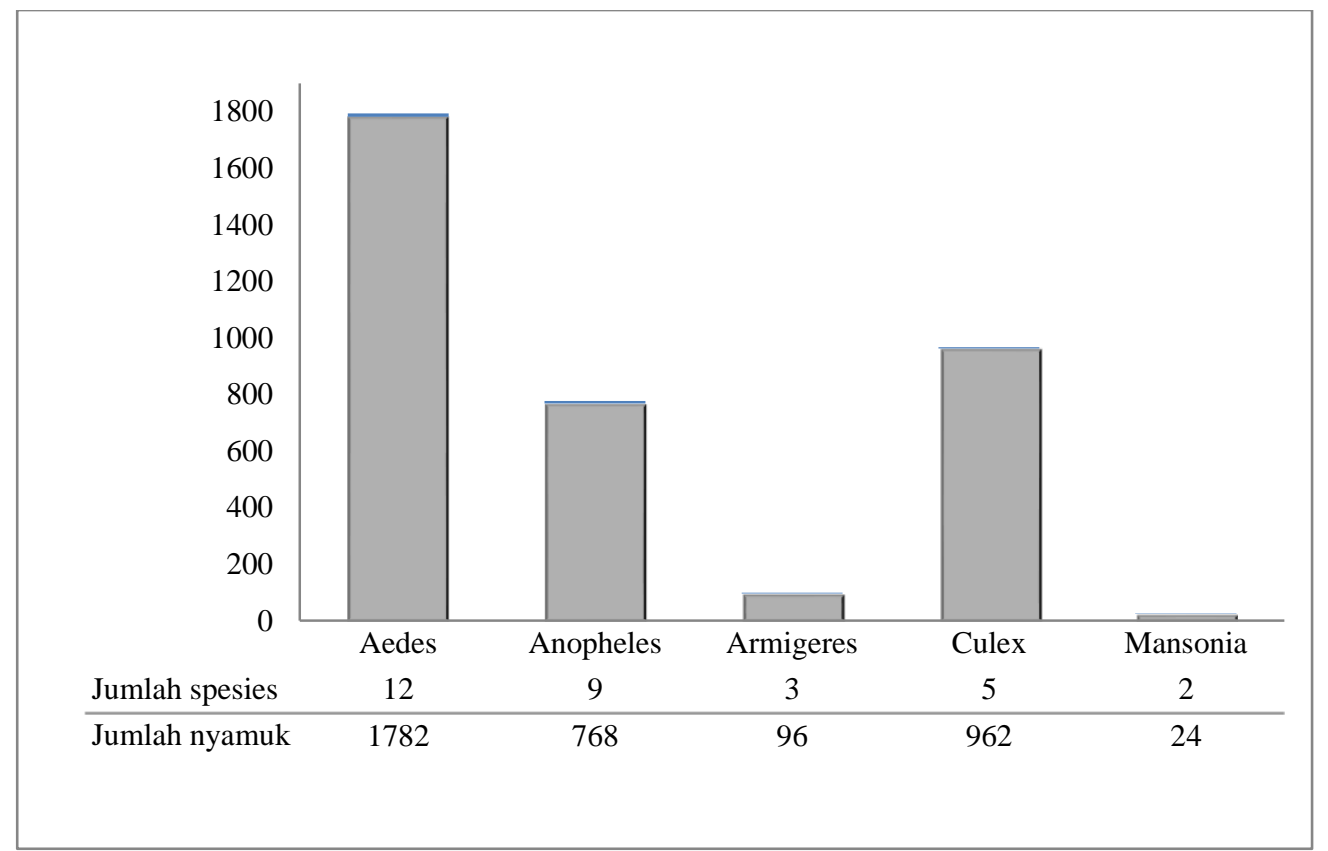

Gambar 2. Jumlah Spesies Nyamuk yang Tertangkap Berdasarkan Genus di Kabupaten Sarmi Tahun 2015.

Nama-nama spesies nyamuk yang tertangkap berdasarkan genus beserta jumlahnya ditampilkan pada Tabel 1. Pada genus Aedes, spesies yang mendominasi adalah $A e$. andamanensis sebanyak 480 ekor; dari genus Anopheles yang paling banyak adalah An. farauti yakni 342 ekor; dari genus Armigeres ada $A r$. subalbatus sebanyak 86 ekor; dari genus Culex yakni $C x$. tritaeniorhynchus sebanyak 454 ekor; dan dari genus Mansonia hanya ada dua spesies yaitu $M a$. dives sebanyak empat ekor dan $M a$. papuensis sebanyak 20 ekor. Sesuai referensi/pustaka dari berbagai sumber mengenai vektor filariasis, ada lima spesies nyamuk di Kabupaten Sarmi yang pernah dikonfirmasi sebagai vektor filariasis di Indonesia, yakni An. farauti, An. koliensis, An. punctulatus, CX. quinquefasciatus, dan Ma. dives ${ }^{6,8}$. Adapun empat spesies dinyatakan sebagai potensial vektor yakni $A n$. peditaeniatus $9,7, A n$. tesselatus $^{8}$, Ar. subalbatus $^{6}$, dan Ma. papuensis. ${ }^{10}$

Tabel 1. Jumlah Individu Nyamuk Tertangkap pada Enam Ekosistem di Kabupaten Sarmi Tahun 2015

\begin{tabular}{|c|c|c|c|c|c|}
\hline \multicolumn{2}{|l|}{ Aedes } & \multicolumn{2}{|c|}{ Anopheles } & \multicolumn{2}{|l|}{ Armigeres } \\
\hline Ae. aegypti & 14 & An. annulatus & 16 & Ar. aureolineatus & 2 \\
\hline Ae. albopictus & 103 & An. argyropus & 5 & Ar. kesseli & 8 \\
\hline Ae. andamanensis & 480 & An. farauti* & 342 & Ar. subalbatus* & 86 \\
\hline Ae. caecus & 86 & An. longirostris & 52 & \multicolumn{2}{|l|}{ Culex } \\
\hline Ae. cancuiformes & 1 & An. kochi & 5 & Cx. gelidus & 67 \\
\hline Ae. gubernatonis & 1 & An. koliensis* & 220 & Cx. hutchinsoni & 24 \\
\hline Ae. imprimens & 19 & An. peditaeniatus* & 15 & Cx. quinquefasciatus* & 107 \\
\hline Ae. mediolineatus & 203 & An. punctulatus* & 103 & Cx. tritaeniorhynchus & 454 \\
\hline Ae. ostentatio & 471 & An. tessellatus* & 10 & Cx. vishnui & 312 \\
\hline Ae. poicilius & 6 & & & \multicolumn{2}{|l|}{ Mansonia } \\
\hline Ae. vexans & 371 & & & Ma. dives* & 4 \\
\hline Ae. vigilax & 27 & & & Ma. papuensis* & 20 \\
\hline
\end{tabular}

*) telah dikonfirmasi sebagai vektor/potensial vektor filariasis 
Tabel 2. Jumlah Individu Spesies Vektor Filariasis Berdasarkan Lingkungan/Habitat Spesifik di Kabupaten Sarmi Tahun 2015

\begin{tabular}{|c|c|c|c|c|c|}
\hline No & Spesies & $\begin{array}{c}\text { Hutan } \\
\text { Sekunder }\end{array}$ & Hutan Primer & $\begin{array}{c}\text { Rumput/Sawah/ } \\
\text { Kebun Cokelat }\end{array}$ & Semak \\
\hline 1 & An. farauti & 176 & 100 & 2 & 64 \\
\hline 2 & An. koliensis & 17 & 4 & 4 & 195 \\
\hline 3 & An. peditaeniatus & 15 & 0 & 0 & 0 \\
\hline 4 & An. punctulatus & 93 & 0 & 10 & 0 \\
\hline 5 & An. tessellatus & 10 & 0 & 0 & 0 \\
\hline 7 & Cx. quinquefasciatus & 7 & 0 & 87 & 11 \\
\hline 8 & Ma. dives & 4 & 0 & 0 & 0 \\
\hline \multirow[t]{2}{*}{9} & Ma. papuensis & 1 & 0 & 0 & 0 \\
\hline & Jumlah & 350 & 104 & 153 & 270 \\
\hline
\end{tabular}

Lingkungan/habitat spesifik yang ditemukan pada tiap ekosistem dirangkum menjadi empat jenis, yakni hutan sekunder, hutan primer, semak, dan rumput/sawah/kebun coklat. Pada Tabel 2 terlihat bahwa An. farauti dan $A n$. koliensis ditemukan pada semua jenis lingkungan.

Berdasarkan metode penangkapannya terdapat spesies yang lebih banyak ditemukan pada penangkapan dengan metode umpan orang dibandingkan dengan umpan ternak. Spesiesspesies tersebut adalah An. koliensis, An. punctulatus, CX. quinquefasciatus, dan. Ma. papuensis. Armigeres subalbatus paling banyak tertangkap pada penangkapan nyamuk istirahat/resting di pagi hari. Pada penangkapan dengan metode umpan orang menunjukkan bahwa spesies dari genus Anopheles lebih banyak tertangkap di luar rumah, meskipun pada $A n$. koliensis perbedaan jumlahnya tidak terlalu jauh. Pada spesies dari genus Mansonia, semua spesies nyamuk tertangkap di luar rumah. Nyamuk $A r$. subalbatus dan Cx. quinquefasciatus lebih banyak tertangkap di dalam rumah. Keterangan lebih lengkap ditampikan pada Tabel 3.

Tabel 3. Jumlah Individu Spesies Vektor Filariasis Berdasarkan Metode Penangkapan di Kabupaten Sarmi Tahun 2015

\begin{tabular}{llccccccc}
\hline \multirow{2}{*}{ No } & \multicolumn{3}{c}{ Nama } & \multicolumn{3}{c}{ Metode Umpan Orang } & \multicolumn{3}{c}{ Metode Resting } \\
\cline { 3 - 9 } & & Dalam & Luar & Jumlah & SKT* & ABT** & Jaring & Jumlah \\
\hline 1 & An. farauti & 25 & 143 & 168 & 8 & 165 & 1 & 174 \\
2 & An. koliensis & 82 & 98 & 180 & 3 & 32 & 5 & 40 \\
3 & An. peditaeniatus & 0 & 4 & 4 & 0 & 11 & 0 & 11 \\
4 & An. punctulatus & 9 & 86 & 95 & 0 & 8 & 0 & 8 \\
5 & An. tessellatus & 0 & 1 & 1 & 0 & 9 & 0 & 9 \\
6 & Ar. subalbatus & 15 & 7 & 22 & 23 & 19 & 22 & 64 \\
7 & Cx. quinquefasciatus & 52 & 32 & 84 & 9 & 11 & 3 & 23 \\
8 & Ma. dives & 0 & 4 & 4 & 0 & 0 & 0 & 0 \\
9 & Ma. papuensis & 0 & 19 & 19 & 0 & 1 & 0 & 1 \\
\hline
\end{tabular}

Keterangan: ${ }^{*}$ SKT $=$ sekitar kandang ternak; ${ }^{* *} \mathrm{ABT}=$ Animal Baited Trap

Perhitungan kepadatan spesies nyamuk mengisap darah manusia per jam dalam satu malam bervariasi di tiap ekosistem. Pada ekosistem yang jauh dari pemukiman, penangkapan nyamuk hanya dilakukan di luar rumah sehingga hanya kepadatan dengan metode umpan orang luar yang didapatkan. Nilai MHD tertinggi ada pada An. farauti di ekosistem PJP dengan nilai MHD mendekati 1 (Tabel 4). 
Tabel 4. Nilai Kepadatan Menggigit Per Orang Per Jam (Man Hour Density) Spesies Tersangka Vektor Filariasis di Kabupaten Sarmi Tahun 2015

\begin{tabular}{|c|c|c|c|c|c|c|c|c|c|c|}
\hline \multirow{3}{*}{ No } & \multirow{3}{*}{ Spesies } & \multicolumn{9}{|c|}{ Man Hour Density (MHD) } \\
\hline & & \multicolumn{2}{|c|}{ HDP } & \multirow{2}{*}{$\begin{array}{c}\text { HJP } \\
\text { UOL }\end{array}$} & \multicolumn{2}{|c|}{ NHDP } & \multirow{2}{*}{$\begin{array}{c}\text { NHJP } \\
\text { UOL } \\
\end{array}$} & \multicolumn{2}{|c|}{ PDP } & \multirow{2}{*}{$\begin{array}{l}\text { PJP } \\
\text { UOL }\end{array}$} \\
\hline & & UOD & UOL & & UOD & UOL & & UOD & UOL & \\
\hline 1 & An. farauti & 0.01 & 0.02 & 0.03 & & & 0.16 & 0.20 & 0.15 & 0.83 \\
\hline 2 & An. koliensis & 0.01 & 0.00 & 0.09 & 0.01 & 0.03 & 0.03 & 0.67 & 0.64 & 0.03 \\
\hline 3 & An. peditaeniatus & & & & & & 0.03 & & & \\
\hline 4 & An. punctulatus & 0.06 & 0.00 & 0.53 & 0.02 & 0.07 & 0.12 & & & \\
\hline 5 & An. tessellatus & & & & & & 0.01 & & & \\
\hline 6 & Ar. subalbatus & 0.01 & 0.03 & & 0.09 & 0.01 & & 0.03 & 0.02 & \\
\hline 7 & Cx. quinquefasciatus & & & & 0.39 & 0.21 & 0.02 & 0.04 & 0.04 & \\
\hline 8 & Ma. dives & & & 0.01 & & & 0.03 & & & \\
\hline 9 & Ma. papuensis & & & & & & 0.06 & & & 0.10 \\
\hline
\end{tabular}

Keterangan: HDP = hutan dekat pemukiman; HJP = hutan jauh pemukiman; NHDP= non hutan dekat pemukiman; $\mathrm{NHJP}=$ non hutan jauh pemukiman; $\mathrm{PDP}=$ pantai dekat pemukiman; $\mathrm{PJP}=$ pantai jauh pemukiman; $\mathrm{UOD}=\mathrm{umpan}$ orang di dalam rumah; UOL = umpan orang di luar rumah.

Kondisi faktor lingkungan di ekosistem hutan dekat pemukiman (HDP) selama 12 jam penangkapan menunjukkan bahwa suhu ratarata $24,8-28,7^{\circ} \mathrm{C}$, kelembapan berkisar antara 85,4-95,2\%, dan kecepatan angin $0 \mathrm{~m} /$ det. Armigeres subalbatus banyak tertangkap di saat senja, sedangkan An. punctulatus tertangkap paling banyak pada jam 01.00-02.00 dan selanjutnya ada pada jam 02.00-06.00 WIT
(Gambar 3). Pada Gambar 4, terlihat bahwa di ekosistem hutan jauh pemukiman (HJP), An. punctulatus tertangkap di sepanjang malam dengan puncak kepadatan tertinggi pada jam 02.00-03.00 WIT. Kondisi faktor lingkungan di ekosistem HJP selama 12 jam penangkapan menunjukkan bahwa suhu rata-rata $24-27^{\circ} \mathrm{C}$, kelembapan berkisar antara 95,9-99\%, dan kecepatan angin 0-0,1 m/det.

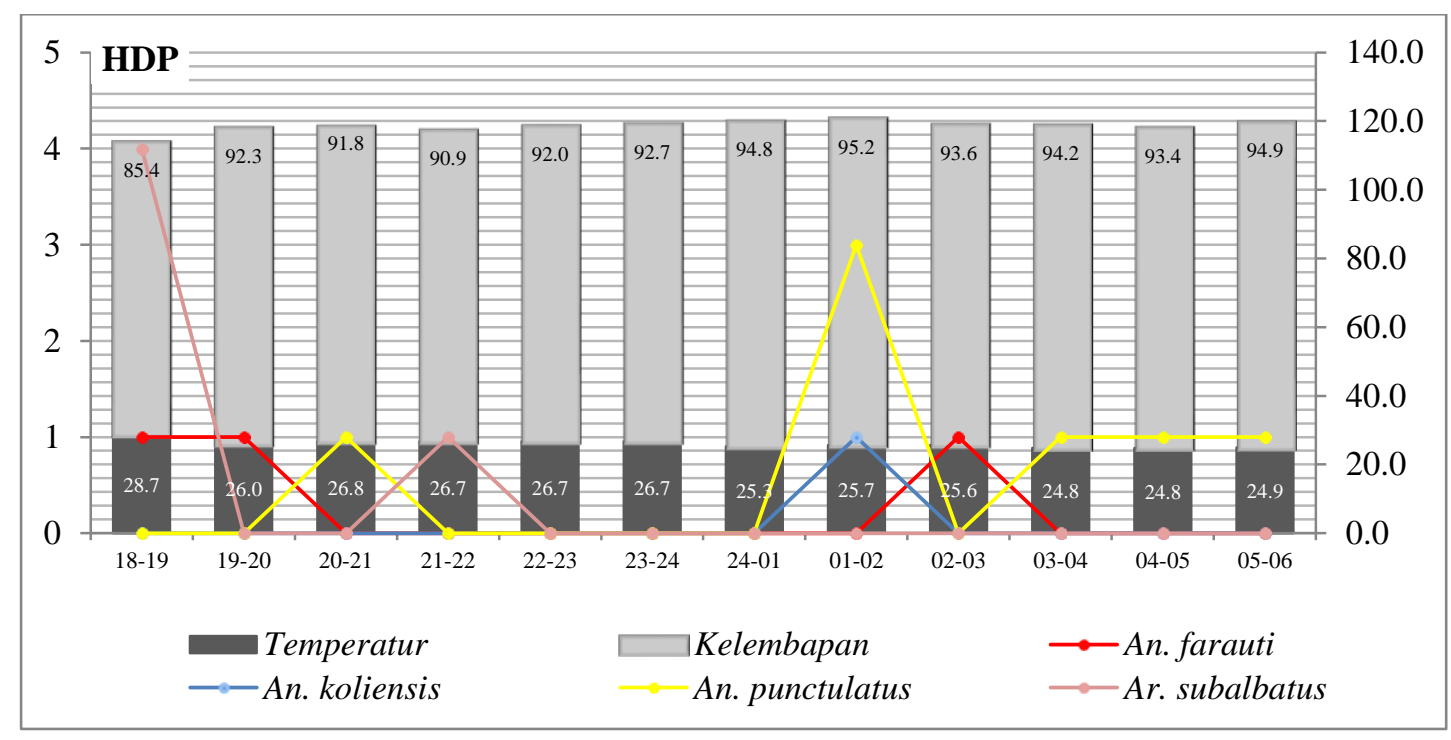

Gambar 3. Jumlah Spesies Tersangka Vektor Filariasis Tertangkap per Jam pada Ekosistem HDP di Kabupaten Sarmi Tahun 2015. 


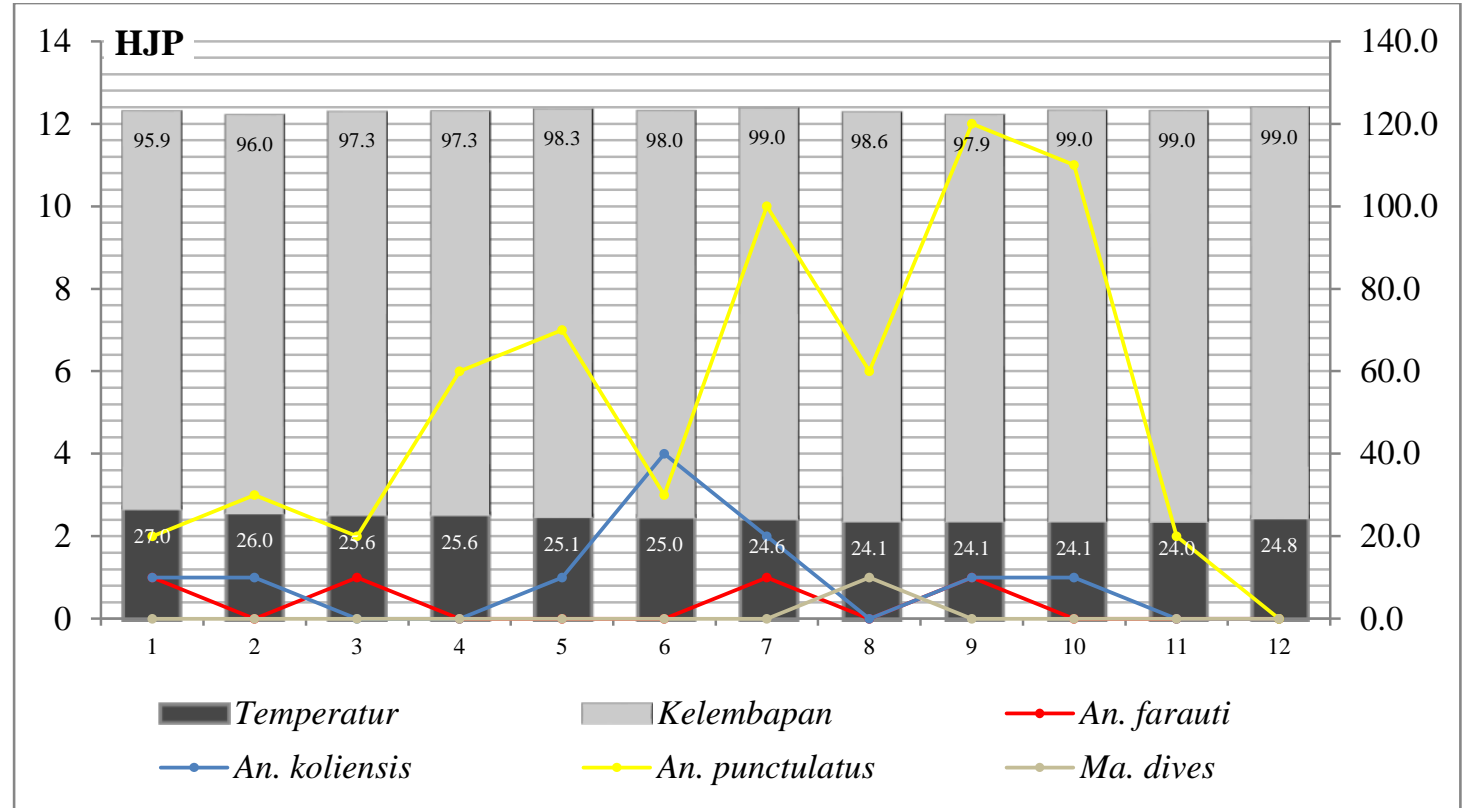

Gambar 4. Jumlah Spesies Tersangka Vektor Filariasis Tertangkap per Jam pada Ekosistem HJP di Kabupaten Sarmi Tahun 2015.

Spesies Cx. quinquefasciatus tertangkap di sepanjang malam pada ekosistem non hutan dekat pemukiman (NHDP), dengan puncak jumlah tertinggi pada jam 02.00-03.00 WIT, sedangkan An. farauti mendominasi penangkapan di ekosistem non hutan jauh pemukiman (NHJP) namun tidak sepanjang malam. Kondisi faktor lingkungan di ekosistem NHDP selama 12 jam penangkapan adalah sebagai berikut: suhu rata-rata $23,4-26,1^{\circ} \mathrm{C}$, kelembaban berkisar antara 88,8-93,8\%, dan kecepatan angin 0-0,7 $\mathrm{m} /$ det, sedangkan kondisi faktor lingkungan di ekosistem NHJP selama 12 jam penangkapan suhu rata-rata $26-29,7^{\circ} \mathrm{C}$, kelembapan berkisar antara 84,2-94,3\%, dan kecepatan angin $0 \mathrm{~m} /$ det (Gambar 5-6).

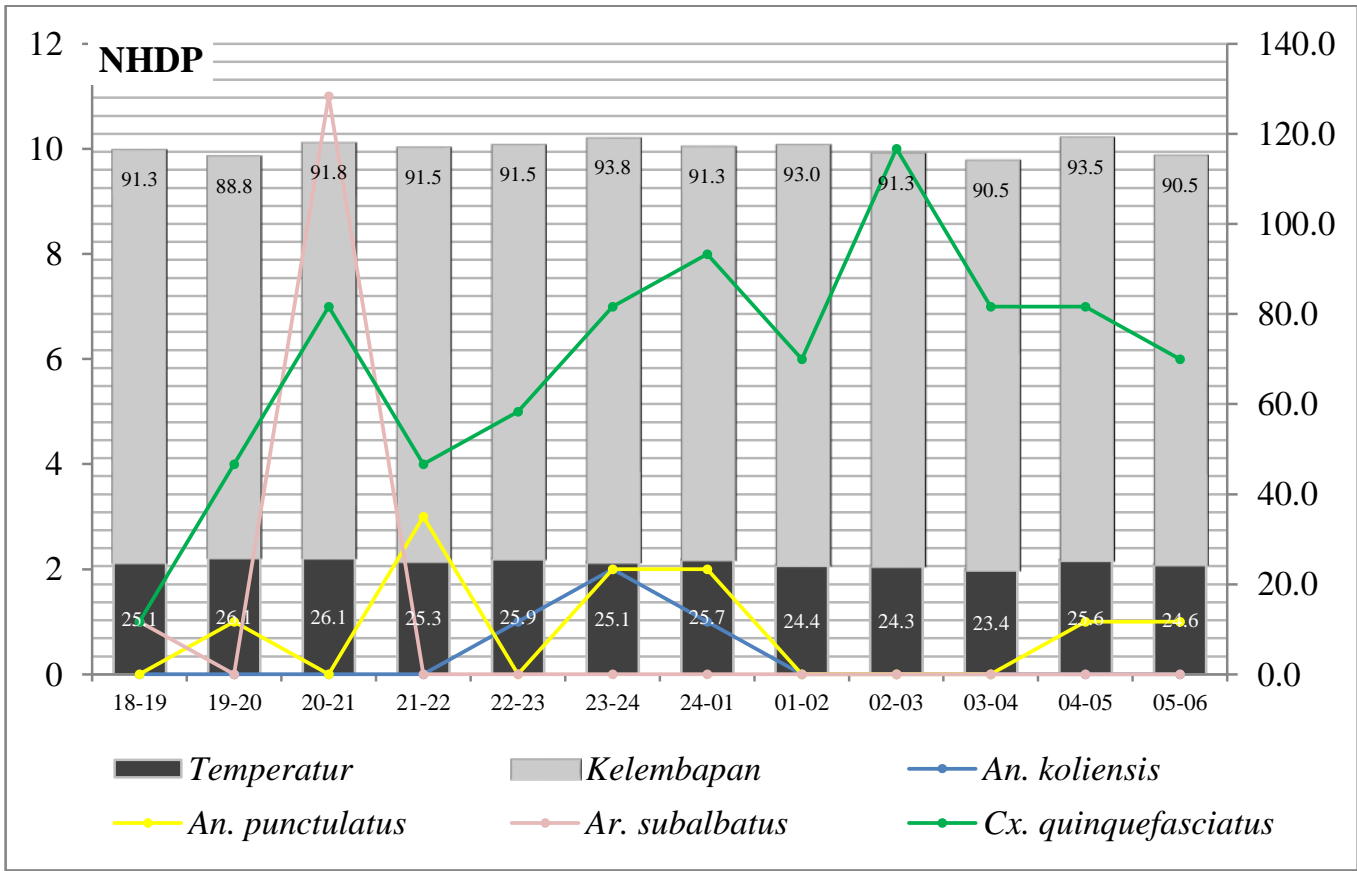

Gambar 5. Jumlah Spesies Tersangka Vektor Filariasis Tertangkap per Jam pada Ekosistem NHDP di Kabupaten Sarmi Tahun 2015. 


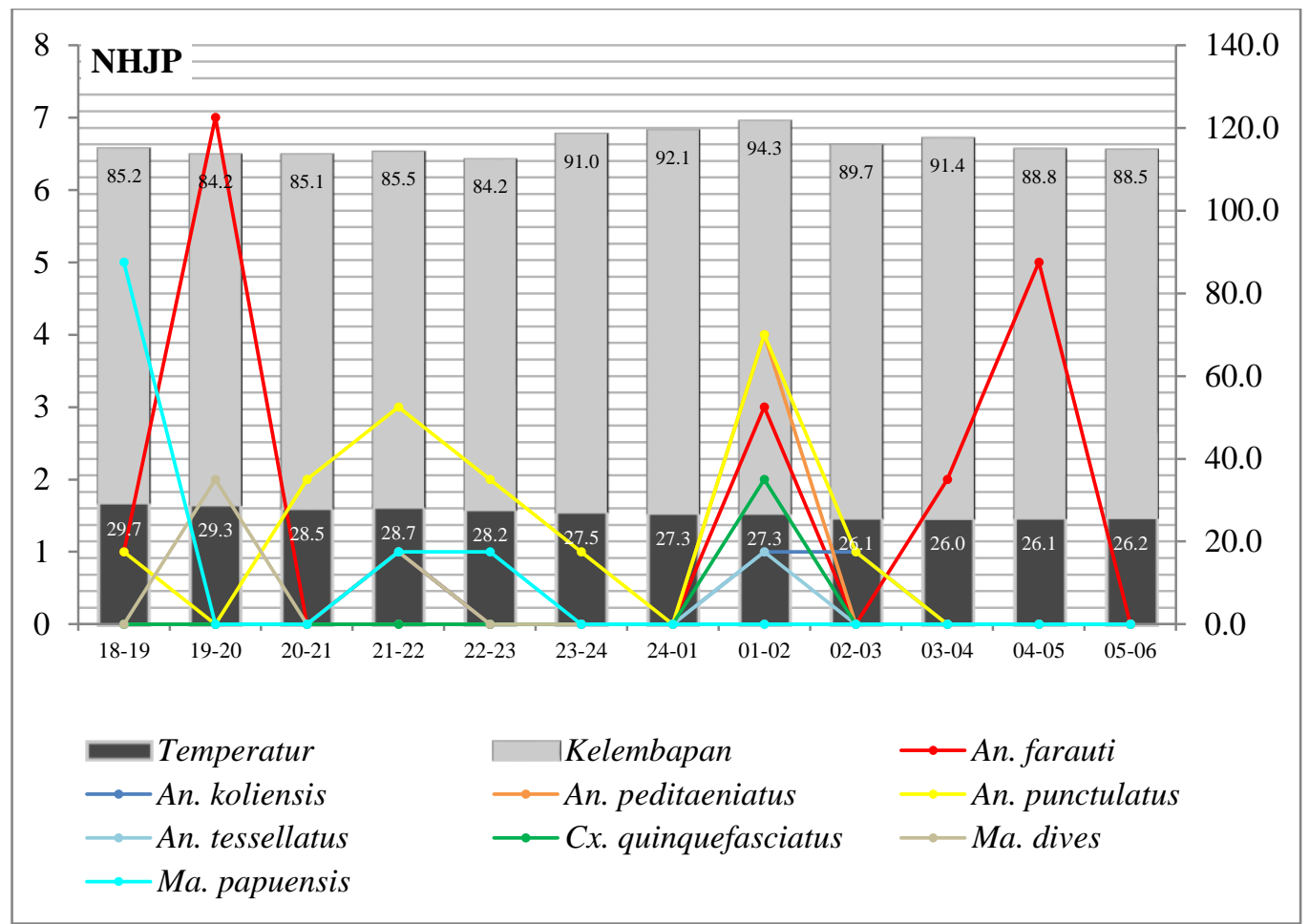

Gambar 6. Jumlah Spesies Tersangka Vektor Filariasis Tertangkap per Jam pada Ekosistem NHJP di Kabupaten Sarmi Tahun 2015.

Pada ekosistem pantai dekat pemukiman (PDP), An. koliensis tertangkap di sepanjang malam dan paling banyak tertangkap pada jam 04.00-05.00 WIT, sedangkan An. farauti paling banyak tertangkap di jam 24.00-01.00 WIT. Kondisi faktor lingkungan di ekosistem PDP selama 12 jam penangkapan adalah sebagai berikut: suhu rata-rata $25-26,2^{\circ} \mathrm{C}$, kelembapan berkisar antara $48-53,7 \%$, dan kecepatan angin
$0 \mathrm{~m} /$ det (Gambar 7). Pada ekosistem pantai jauh pemukiman (Gambar 8), An. farauti tertangkap hampir di sepanjang malam dengan jam paling banyak tertangkap di jam 22.00-23.00 WIT dan jam 03.00-04.00 WIT. Kondisi faktor lingkungan di ekosistem PJP selama 12 jam penangkapan adalah sebagai berikut: suhu rata-rata $24,8-$ $26,8^{\circ} \mathrm{C}$, kelembapan berkisar antara $94-99 \%$, dan kecepatan angin $0 \mathrm{~m} /$ det.

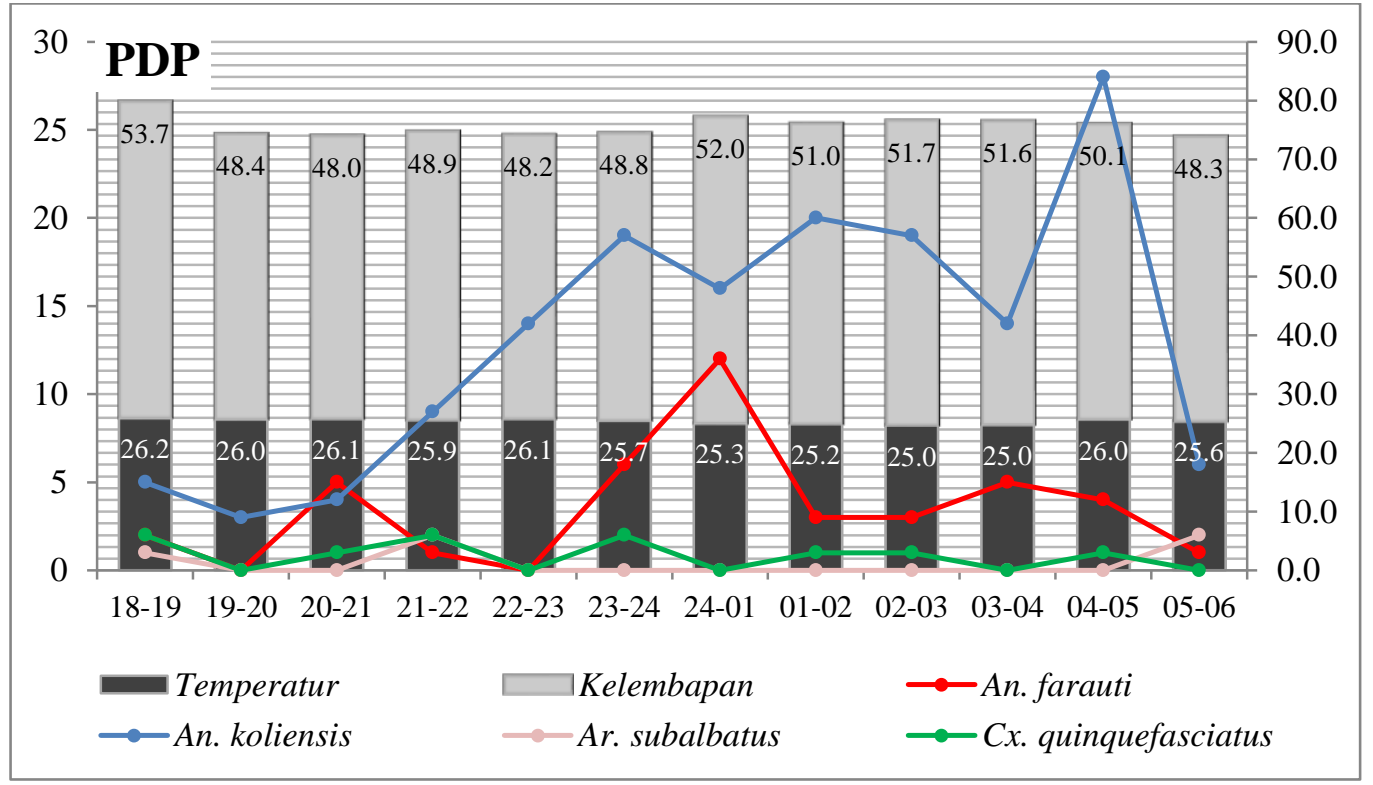

Gambar 7. Jumlah Spesies Tersangka Vektor Filariasis Tertangkap per Jam pada Ekosistem PDP di Kabupaten Sarmi Tahun 2015. 


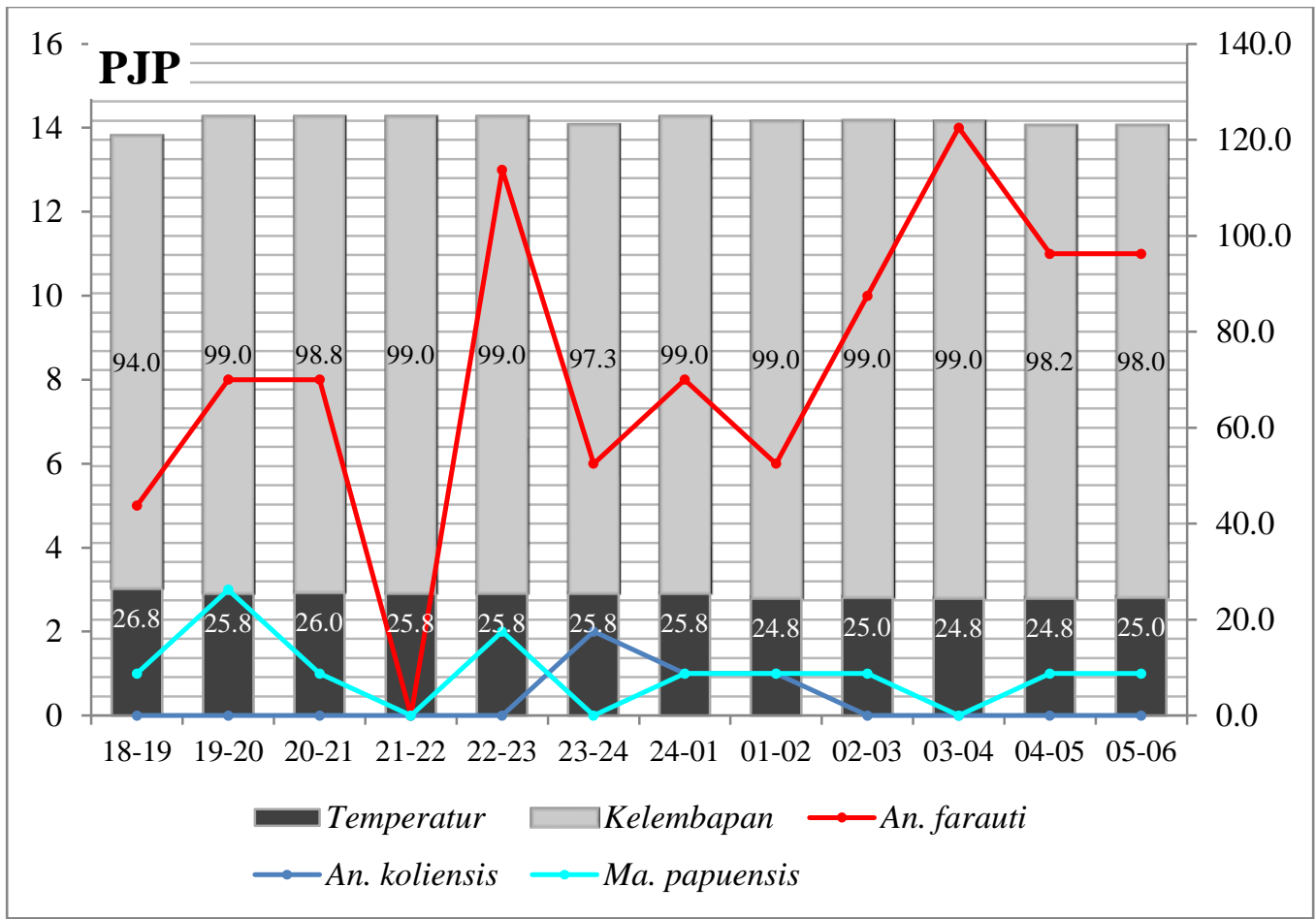

Gambar 8. Jumlah Spesies Tersangka Vektor Filariasis Tertangkap per Jam pada Ekosistem PJP di Kabupaten Sarmi Tahun 2015

Hasil uji korelasi Pearson menunjukkan bahwa pada nilai signifikansi antara variabel lingkungan (temperatur dan kelembapan) dan metode penangkapan menunjukkan nilai $\mathrm{P}>$ 0,05 . Pada variabel temperatur, tidak terdapat korelasi antara temperatur dengan jumlah nyamuk dengan sig 0,967 $(\mathrm{P}>0,05)$ dengan koefisien korelasi 0,04. Demikian juga untuk variabel kelembapan, menunjukkan tidak terdapat korelasi antara variabel kelembaban dengan jumlah nyamuk dengan nilai signifikansi sebesar 0,234 $(P>0,05)$ dengan arah korelasi negatif sebesar $-0,11$. Dan tidak ada perbedaan $(\mathrm{P}>0,05)$ di antara metode penangkapan terhadap jumlah nyamuk dengan nilai signifikansi sebesar 0,337.

\section{PEMBAHASAN}

Hasil penangkapan di wilayah Kabupaten Sarmi menunjukkan bahwa pada tipe ekosistem non hutan, jumlah nyamuk yang tertangkap lebih banyak dibandingkan tipe ekosistem yang lain, sedangkan pada ekosistem hutan jumlah nyamuk relatif lebih sedikit. Hal ini dimungkinkan pada ekosistem non hutan, terdapat habitat atau lingkungan yang lebih disukai oleh nyamuk untuk hidup dibandingkan pada ekosistem hutan. Genus nyamuk yang mendominasi adalah Aedes dengan jumlah spesies sebanyak 12. Namun, dari 12 spesies tersebut, tidak ada spesies yang pernah dikonfirmasi sebagai vektor filariasis. Spesies dari genus Aedes yang diketahui menjadi vektor filariasis adalah Aedes kochi. ${ }^{6}$ Aedes kochi juga dikenal sebagai Ochlerotatus kochi merupakan salah satu spesies vektor potensial dalam transmisi LF di New Guinea. 8,11

Pada genus Anopheles, terdapat empat dari sembilan spesies yang pernah dinyatakan sebagai vektor dan potensial vektor filariasis yakni An. farauti, An. koliensis, An. punctulatus, dan An. peditaeniatus.

Spesies An. farauti, An. koliensis, dan An. punctulatus yang termasuk ke dalam Punctulatus Group dan diketahui terdapat di Maluku, Indonesia sampai Papua New Guinea, Kepulauan Solomon dan Vanuatu. Ketiganya merupakan vektor utama filariasis. ${ }^{11}$ Vektor utama LF di Papua New Guinea adalah nyamuk An farauti, An. punctulatus, An koliensis dan lainnya, walaupun nyamuk Culex juga pernah dilaporkan infektif. Infeksi alami An. farauti pernah ditemukan sebesar $46,2 \%, 7,1 \%$ pada $A n$. koliensis, dan $8,3 \%$ pada An. punctulatus. ${ }^{10}$ Anopheles peditaeniatus diketahui menjadi vektor potensial untuk B. malayi di Sumatra ${ }^{9}$, sedangkan An. tessellatus dinyatakan sebagai vektor sekunder W. bancrofti. ${ }^{8}$

Culex quinquefasciatus adalah salah satu spesies Culex yang ditemukan dengan jumlah melimpah dalam penelitian ini. Penelitian lain di Pulau Mafia, Tanzania berhasil mengumpulkan sebanyak 3.866 vektor nyamuk filariasis dengan perangkap cahaya Centre for Disease Control and Prevention (CDC), kemudian dibedah dan diperiksa untuk mengetahui infeksi dan 
infektivitas dengan $W$. bancrofti. Sebanyak sembilan ekor $(0,23 \%) \quad C x$. quinquefasciatus ditemukan terinfeksi larva stadium L1, L2, dan L3 $W$. bancrofti, 3 di antaranya $(0,08 \%)$ infektif. 12 Di Indonesia, penelitian Ramadhani et al di Kelurahan Pabean, Pekalongan menemukan stadium L3 W. bancrofti pada Cx. quinquefasciatus yang tertangkap baik di dalam maupun di luar ruangan dengan nilai infektif sebesar 34,4\%.13 Penelitian Astuti et al menunjukkan bahwa $C x$. quinquefasciatus merupakan tersangka vektor LF dominan di Kec. Majalaya, Jawa Barat karena telah ditemukan nyamuk berikut habitat perkembangbiakannya di lokasi tersebut. ${ }^{14}$

Adapun dari genus Mansonia, ditemukan dua jenis yaitu Ma. dives dan Ma. papuensis. Spesies $M a$. dives diketahui sebagai vektor sekunder $B$. malayi di Sulawesi. ${ }^{9}$ Mansonia dives juga merupakan vektor sekunder B. Malayi di kawasan Selatan Thailand, spesies ini juga banyak ditemukan di Kabupaten Muaro Jambi. ${ }^{15}$ Penelitian lain yang dilakukan di daerah Bamgi Ia, Barat Data New Guinea, sebanyak 32 dari 42 nyamuk $M a$. papuensis yang tertangkap ditemukan terinfeksi larva stadium infektif. Namun nyamuk ini memiliki tingkat kematian yang tinggi, dan hanya satu ekor yang bertahan hidup sampai hari ke- $12 .{ }^{10}$

Penelitian yang dilakukan di Peninsular Malaysia menemukan 60 nyamuk Ar. subalbatus positif, 27 di antaranya ditemukan stadium L3 $B$. pahangi. Brugia pahangi, merupakan spesies cacing filarial pada mamalia yang berhubungan erat dengan $B$. malayi, biasanya terdapat pada anjing dan kucing. Penelitian eksperimen yang menginfeksikan $B$. pahangi pada manusia menunjukkan gejala lymphatic filariasis, namun hampir tidak menghasilkan mikrofilaria. ${ }^{16}$

Dalam penelitian ini habitat spesifik yang banyak ditemukan spesies vektor filariasis adalah kategori hutan sekunder dan semak. Hutan sekunder merupakan hutan yang sudah mengalami intervensi manusia seperti adanya aktivitas penebangan oleh manusia untuk membuka lahan. Penelitian sebelumnya di Kabupaten Sarmi menunjukkan bahwa vegetasi yang berhubungan dengan breeding place dan resting place yang terdapat di lokasi penelitian adalah: tumbuhan air, hutan, semak liar, dan pantai. ${ }^{17}$ Berdasarkan jenis habitat/lingkungan, An. farauti dan An. punctulatus paling banyak ditemukan di hutan sekunder. Survei bioekologi nyamuk Anopheles spp. yang dilakukan di Kampung Kwor Kabupaten Tambrauw terdiri dari jenis nyamuk An. farauti, An. punctulatus, dan An. koliensis. Tipe habitat jentik adalah saluran air, kolam, dan bekas galian tanah eskavator. ${ }^{18}$
Adapun An. koliensis diperoleh paling banyak di habitat semak. Hasil observasi dalam penelitian mengenai pengaruh lingkungan biologi dan upaya pelayanan kesehatan terhadap kejadian filariasis limfatik menunjukkan bahwa analisis secara statistik variabel keberadaan semak liar sekitar rumah < 500 meter, tidak memiliki pengaruh yang signifikan terhadap kejadian filariasis limfatik. ${ }^{17}$ Namun penelitian lain menyebutkan faktor risiko filariasis di Kelurahan Bandengan, Kertoharjo, Banyurip Ageng, dan Kuripan Lor berupa keberadaan semak-semak. ${ }^{19}$

Spesies $C x$. quinquefasciatus dan $A r$. subalbatus ditemukan paling banyak di lingkungan rumput/sawah/kebun coklat. Hasil penelitian di Thailand menunjukkan selama musim hujan di tahun 2008, koleksi nyamuk dewasa dari 24 lokasi, mewakili 6 tipe habitat mulai dari hutan ke perkotaan. Kelimpahan nisbi nyamuk paling tinggi berada di sawah dan terendah di hutan. Indeks keragaman menunjukkan bahwa fauna nyamuk lebih beragam di pedesaan dan kurang beragam di habitat sawah. ${ }^{20}$ Spesies $C x$. quinquefasciatus diketahui juga mendominasi pada ekosistem NHDP. Kondisi ini bersesuaian dengan karakteristik habitat nyamuk vektor penular mikrofilaria spesies $W$. bancrofti. Mikrofilaria ini merupakan tipe perkotaan (urban), yaitu daerahdaerah perkotaan kumuh dengan kepadatan penduduk yang cukup tinggi dan drainase yang buruk. Hal ini mengakibatkan banyak genangan air kotor sebagai habitat yang cocok untuk nyamuk $C x$. quinquefasciatus. ${ }^{21}$ Ditemukan beberapa tipe habitat perkembangbiakan vektor nyamuk filariasis dengan flora dan fauna yang sangat mendukung terbentuknya tempat perindukan nyamuk potensial yaitu genangan air atau kubangan dan sungai kecil yang tidak pernah kering sepanjang tahun, ${ }^{21} C X$ quinquefasciatus merupakan vektor $W$. bancrofti tipe perkotaan. Di wilayah yang cocok untuk $C x$. quinquefasciatus, kondisi sanitasi dan perumahan, dapat memainkan peran penting dalam penularan penyakit. ${ }^{2}$ Spesies ini adalah nyamuk yang dominan dengan kelimpahan nisbi paling tinggi di Kota Pekalongan. Saluran pembuangan air limbah yang tercemari oleh limbah cair industri (cat dan batik) sepanjang permukiman penduduk merupakan tempat perkembangbiakan nyamuk ini. ${ }^{22}$

Culex quinquefasciatus memiliki kecocokan untuk tinggal di lingkungan perkotaan dan mencari darah manusia di dalam ruangan maupun di luar ruangan. Penelitian di Kabupaten Bandung, Jawa Barat menunjukkan bahwa dari 132 nyamuk $C x$. quinquefasciatus yang ditemukan, sebanyak 55\% tertangkap dengan 
metode umpan orang, dan 30\% ( $\mathrm{n}=40 / 132)$ tertangkap di luar ruangan. ${ }^{14}$ Penelitian lain menyebutkan bahwa nyamuk ini diketahui aktif di malam hari dan ditemukan bahwa dominan nyamuk yang tertangkap yaitu oleh umpan manusia di Calcutta. ${ }^{23}$ Dalam penelitian ini, spesies $C x$. quinquefasciatus banyak ditemukan dengan metode penangkapan umpan orang di luar rumah.

Spesies lain yang banyak tertangkap dengan metode umpan orang adalah An. koliensis, An. punctulatus, dan Ma. papuensis. Ini menunjukkan ketertarikan yang lebih besar dari spesiesspesies ini untuk mengisap darah manusia, dibandingkan darah ternak. Spesies yang mempunyai kecenderungan sifat antropofilik pada dasarnya lebih berpotensi untuk menularkan filariasis dibandingkan nyamuk yang bersifat zoofilik. Terlebih jika spesies tersebut lebih suka berada di dalam rumah dibandingkan luar rumah. Jika spesies nyamuk lebih suka berada di dalam rumah, potensi nyamuk untuk kontak dengan manusia semakin tinggi, karena nyamuk akan membuat sarang untuk bertelur dan beristirahat di dalam rumah. Anopheles farauti ditemukan dalam jumlah yang hampir sama antara metode penangkapan umpan manusia maupun umpan ternak. Hasil penelitian mengenai preferensi pemilihan inang nyamuk Anopheles di Papua New Guinea menunjukkan bahwa An. punctulatus dan An. farauti lebih banyak menghisap darah manusia dibandingkan darah mamalia lainnya, meskipun dikatakan bahwa kedua spesies tersebut dikategorikan sebagai opportunistic blood feeders. ${ }^{24}$

Anopheles punctulatus, Cx. quinquefasciatus, An. koliensis, dan An. farauti tertangkap di sepanjang malam pada ekosistem yang berbeda. Hal ini menunjukkan potensi nyamuk untuk menggigit sepanjang malam. Seseorang akan tertular filariasis setelah mendapat gigitan nyamuk infektif hingga ribuan kali. Karena itu semakin lama seseorang tinggal di daerah endemis semakin tinggi risiko tertular karena sering mendapat gigitan nyamuk vektor filariasis. ${ }^{25}$

Anopheles farauti mendominasi penangkapan di ekosistem non hutan jauh pemukiman (NHJP), dan pada ekosistem pantai dekat pemukiman (PDP). Berdasarkan nilai kepadatan, An. farauti memiliki nilai MHD tertinggi dibandingkan spesies yang lain. Pada ekosistem pantai jauh pemukiman An. farauti tertangkap hampir di sepanjang malam. Penelitian Russel menyatakan ada kecenderungan kuat untuk mencari makan di awal malam, dengan 82\% ( $\mathrm{n}=934)$ dari $\mathrm{An}$. farauti ditangkap antara jam 18.00 dan 21.00 jam (early feeding), dan hanya $18 \%(\mathrm{n}=204)$ tertangkap antara jam $00.00-06.00 .^{26}$ Anopheles koliensis tertangkap di sepanjang malam dan paling banyak tertangkap pada jam 04.00-05.00. Spesies An. koliensis juga memiliki nilai MHD tinggi, meskipun tidak setinggi $A n$. farauti namun eksistensinya terdapat pada semua ekosistem. An. koliensis bersifat nokturnal, antropofilik (78\% biasanya terpapar sinar matahari langsung dan menggigit manusia), eksofagik, eksofilik. ${ }^{27}$ Armigeres subalbatus banyak tertangkap di saat senja, An. punctulatus tertangkap paling banyak pada jam 01.00-02.00 dan selanjutnya ada pada jam 02.00-06.00 WIT. Spesies $C X$. quinquefasciatus tertangkap di sepanjang malam pada ekosistem non hutan dekat pemukiman (NHDP), dengan puncak jumlah tertinggi pada jam 02.00-03.00 WIT. Nyamuk Culex sp. menggigit mangsa pada rentang waktu pukul 19.00-04.00 WIB dengan suhu $27^{\circ} \mathrm{C}$, kelembaban udara 99-100\%, dan pencahayaan 60-65 lux serta kecepatan angin 3-5 km/jam. ${ }^{28}$ Kepadatan spesies $C x$. quinquefasciatus mencapai puncak pada jam 9-11 malam di luar rumah dan antara jam 12 malam hingga jam 1 dini hari di dalam rumah. ${ }^{14}$ Dalam penelitian ini spesies nyamuk $M a$. dives hanya tertangkap di ekosistem jauh pemukiman dengan metode umpan orang di luar rumah. Penelitian lain di Kalimantan Selatan menunjukkan bahwa nyamuk Ma. dives juga lebih banyak tertangkap di luar rumah selama lima bulan penangkapan yaitu sebesar $56,80 \%$ dan memiliki puncak kepadatan pada pukul 19.00$19.45 .^{29}$

Berdasarkan hasil uji korelasi Pearson diketahui bahwa variabel lingkungan (temperatur dan kelembapan) dan juga metode penangkapan tidak berpengaruh terhadap jumlah nyamuk yang tertangkap. Hasil berbeda ditunjukkan, bahwa kelembapan udara mempunyai hubungan bermakna dengan kepadatan nyamuk Anopheles per orang per malam (MBR). ${ }^{30}$ Demikian pula dengan hasil penelitian di Ghana yang menjelaskan bahwa hasil analisis lingkungan meliputi ketinggian, curah hujan, dan suhu adalah variabel penting yang mendorong distribusi spasial setiap spesies nyamuk, dan perbedaan di antara mereka. ${ }^{31}$

Faktor lingkungan dan iklim memainkan peran penting untuk penularan penyakit yang ditularkan melalui vektor dan diteliti dalam banyak artikel. ${ }^{32,33}$ Hasil penelitian ini berbeda dengan penelitian sebelumnya, seperti yang dijlelaskan dalam penelitian lain yang bersesuaian dengan kondisi ini bahwa ada faktor-faktor lain yang terlibat dalam kelimpahan spesies. Perbedaan hasil ini dapat disebabkan oleh karakteristik biologis dari spesies yang berbeda. ${ }^{34}$

Hasil penelitian mengenai batas transmisi filariasis menggunakan pemodelan Boosted 
Regression Trees (BRT) menjelaskan bahwa kemungkinan transmisi filariasis meningkat dengan bertambahnya presipitasi, suhu, dan jenis vegetasi tertentu namun menurun dengan meningkatnya ketinggian. ${ }^{2}$

\section{KESIMPULAN}

Variasi spesies tersangka vektor filariasis di Kabupaten Sarmi Provinsi Papua terdiri dari 4 genus dengan 9 spesies vektor/tersangka vektor filariasis yaitu An. farauti, An. koliensis, An. pediateniatus, An. punctulatus, An. tesselatus, An. subalbatus, Cx. quinquefasciatus, Ma. dives, dan Ma. papuensis. Habitat atau lingkungan yang banyak ditemukannya vektor tersangka filariasis adalah hutan sekunder, hutan primer, rumput/sawah/kebun coklat dan semak. Ekosistem di daerah urban yaitu NHDP dan PDP didominasi oleh $C x$. quinquefasciatus sedangkan An. farauti ditemukan di 5 ekosistem HDP, HJP, NHJP, PJP dan PDP.

\section{UCAPAN TERIMA KASIH}

Ucapan terima kasih kami sampaikan kepada Kepala Badan Litbang Kesehatan, Tim Laboratorium Manajemen Data Badan Litbang Kesehatan, dan seluruh enumerator yang terlibat dalam pengumpulan data Vektora 2015.

\section{KONTRIBUSI PENULIS}

Semua penulis yang tercantum dalam artikel ini telah berkontribusi sesuai dengan keahlian masing-masing dengan peran sebagai berikut:

$\begin{array}{lll}\text { Konsep } & : & \text { Milana Salim } \\ & & \text { Mara Ipa } \\ \text { Kurasi Data } & : & \text { Milana Salim } \\ \text { Analisis Data } & : & \text { Olwin Nainggolan } \\ \text { Visualisasi } & : & \text { Milana Salim } \\ & & \text { Mara Ipa } \\ \text { Menulis- } & : & \text { Mara Ipa } \\ \text { Pembuatan } & & \\ \text { Menulis-Mengkaji } & : & \text { Milana Salim } \\ \text { \& Mengedit } & \begin{array}{l}\text { Mara Ipa } \\ \text { Olwin Nainggolan }\end{array}\end{array}$

\section{DAFTAR RUJUKAN}

1. Ichimori $\mathrm{K}$, King JD, Engels D, Yajima $\mathrm{A}$, Mikhailov A, Lammie $P$ et al. Global Programme to Eliminate Lymphatic Filariasis: The Processes Underlying Programme Success. PLoS Negl Trop Dis. 2014; 8. doi:10.1371/journal.pntd.0003328.

2. Cano J, Rebollo MP, Golding N, Pullan RL, Crellen T, Soler A et al. The Global Distribution and Transmission Limits of Lymphatic Filariasis: Past and Present. Parasites and Vectors. 2014; 7: 1-19.

3. Kementerian Kesehatan RI. Profil Kesehatan Indonesia 2015. 2016 doi:351.077 Ind.

4. Dinas Kesehatan Kabupaten Sarmi. Profil Kesehatan Kabupaten Sarmi Tahun 2012. 2013.[thesis].1-80pp.

5. Liesdiawati V. Laporan Provinsi Papua: Riset Khusus Vektor dan Reservoir Penyakit (RIKHUS VEKTORA). : Salatiga. 2015.[thesis].p.

6. Kementerian Kesehatan Republik Indonesia Peraturan Menteri Kesehatan Repubik Indonesia Nomor 94 tahun 2014, tentang Penanggulangan Filariasis. 2014.pp:1-118.

7. Sigit SH. Parasitology and Parasitic Diseases in Indonesia (A Country Report). Proceeding. The 1st Congress of Pederation of. Asian Parasitol (FAP), Japan. 2000; : 7178.

8. Manguin S, Bangs MJ, Pothikasikorn J Chareonviriyaphap T. Review on Global Cotransmission of Human Plasmodium Species and Wuchereria bancrofti by Anopheles Mosquitoes. Infect Genet Evol. 2010; 10: 159-177.

9. Sudomo M, Izhar A, Oemijati S. Lymphatic Filariasis In Indonesia. Ekol. Kesehat. 2002; 1: 37-43.

10. Santoso. Filariasis di Indonesia - Strategi dan Tantangan POPM Filariasis Menuju Eliminasi Tahun 2020. Badan Penelitian dan Pengembangan Kesehatan Kementerian Kesehatan RI. 2016.

11. Beebe NW, Russell T, Burkot TR, Cooper RD. Anopheles punctulatus Group: Evolution, Distribution, and Control. Annu Rev Entomol. 2015; 60: 335-350.

12. Derua YA, Rumisha SF, Batengana BM, Max DA, Stanley G, Kisinza WN et al. Lymphatic Filariasis Transmission on Mafia Islands, Tanzania: Evidence from Xenomonitoring in Mosquito Vectors. PLoS Negl Trop Dis. 2017; 11: 1-13.

13. Tri Ramadhani Soeyoko SS. Culex quinquifasciatus Sebagai Vektor Utama Filariasis Limfatik yang Disebabkan Wuchereria Bancrofti Di Kelurahan Pabean 
Kota Pekalongan. Ekol Kesehat. 2010; 9: 1303-1311.

14. Puji Astuti, Endang, Mara Ipa, Tri Wahono, Andri Ruliansyah, Lukman Hakim $P$, Dhewantara W. The Distribution of Culex spp. (Diptera: Culicidae) in Selected Endemic Lymphatic Filariasis Villages in Bandung District West Java Indonesia. Aspirator. 2017; 9: 61-68.

15. Santoso, Yahya, Salim M. Penentuan Jenis Nyamuk Mansonia sebagai Tersangka Vektor Filariasis Brugia malayi dan Hewan Zoonosis di Kabupaten Muara Jambi. Media Litbang Kesehat. 2014; 24.

16. Muslim A, Fong MY, Mahmud R, Lau YL, Sivanandam S. Armigeres subalbatus Incriminated as a Vector of Zoonotic Brugia pahangi Filariasis in Suburban Kuala Lumpur, Peninsular Malaysia. Parasites and Vectors. 2013; 6: 1.

17. Sipayung M, Wahjuni CU, Devy SR. Pengaruh Lingkungan Biologi dan Upaya Pelayanan Kesehatan terhadap Kejadian Filariasis Limfatik di Kabupaten Sarmi. J Berk Epidemiol. 2012; 2: 263-273.

18. Sandy S, Sasto IHS, Wike I. Survei Entomologi Anopheles spp. di Kampung Bikar dan Kampung Kwor Kabupaten Tambrauw, Papua Barat Entomology Survey of Anopheles spp in Bikar and Kwoor Villages District of Tambrauw, West Papua. JHealthEpidemiolCommunDis. 2016; 2: 1927.

19. Wulandhari SA dan ETP. Analisis Spasial Aspek Kesehatan Lingkungan dengan Kejadian Filariasis di Kota Pekalongan. Unnes J Public Heal. 2017; 6: 1-5.

20. Thongsripong $\mathrm{P}$, Green A, Kittayapong $\mathrm{P}$, Kapan D, Wilcox B, Bennett S. Mosquito Vector Diversity across Habitats in Central Thailand Endemic for Dengue and Other Arthropod-Borne Diseases. PLoS Negl Trop Dis. 2013. doi:10.1371/journal.pntd.0002507.

21. Tallan MM, Mau F. Karakteristik Habitat Perkembangbiakan Vektor Filariasis di Kecamatan Kodi Balaghar Kabupaten Sumba Barat Daya. Aspirator. 2016; 8: 55-62.

22. Ramadhani $\mathrm{T}, \mathrm{Wahyudi} \mathrm{BF}$ Keanekaragaman dan Dominasi Nyamuk di Daerah Endemis Filariasis Limfatik, Kota Pekalongan. J Vektor Penyakit. 2015; 9: 1-8.

23. Bhattacharya S, Basu P, Sajal Bhattacharya C. The Southern House Mosquito, Culex quinquefasciatus: Profile of a Smart Vector. J Entomol Zool Stud JEZS. 2016; 73: 73-81.
24. Keven JB, Reimer L, Katusele M, Koimbu G, Vinit R, Vincent $\mathrm{N}$ et al. Plasticity of Host Selection by Malaria Vectors of Papua New Guinea. Parasit Vectors. 2017; 10: 95.

25. Wahyudi BF, Pramestuti N. Kondisi Filariasis Pasca Pengobatan Massal di Kelurahan Pabean Kecamatan Pekalongan Utara Kota Pekalongan. Balaba. 2016; 12: 55-60.

26. Russell TL, Beebe NW, Bugoro H, Apairamo A, Collins FH, Cooper RD et al. Anopheles farauti is a Homogeneous Population that Blood Feeds Early and Outdoors in the Solomon Islands. Malar J. 2016; 15: 1-7.

27. Sandy S. Bionomi Vektor Malaria Kelompok Anopheles Punculatus (Anopheles Farauti, Anopheles Koliensis, Anopheles Punculatus) Di Provinsi Papua. Balaba. 2014; 10: 47-52.

28. Sukendra DM, Shidqon MA. Description of Feeding Behavior of Culex sp. as Filariasis Vector Wuchereria bancrofti. J Pena Med. 2016; 6: 19-33.

29. Supriyono, Supriyono Tan, Suriyani, Hadi UK. Perilaku Nyamuk Mansonia dan Potensi Reservoar dalam Penularan Filariasis di Desa Gulinggang Kabupaten Balangan Provinsi Kalimantan Selatan. Aspirator. 2017; 9: 1-10.

30. Hadi UK, Sigit SH. Hubungan Iklim, Kepadatan Nyamuk Anopheles dan Kejadian Penyakit Malaria. 2010; 7: 42-53.

31. Souza D De, Kelly-hope L, Lawson B, Wilson $M$, Boakye D. Environmental Factors Associated with the Distribution of Anopheles gambiae s . s in Ghana; an Important Vector of Lymphatic Filariasis and Malaria. 2010; 5. doi:10.1371/journal.pone.0009927.

32. C. M. Liao, T. L. Huang YJL et al. Regional Response of Dengue Fever Epidemics to Interannual Variation and Related Climate Variability,". Stoch Environ Res Risk Assess. 2015; 29, $\mathbf{n}$.

33. You CML and SH. Assessing Risk Perception and Behavioral Responses to Influenza Epidemics: Linking Information Theory to Probabilistic Riskmodeling. Stoch Environ Res Risk Assessment,. 2014; 28, n.

34. Nikookar SH, Fazeli-dinan M, Azarihamidian S, Mousavinasab N, Aarabi M, Ziapour SP et al. Correlation between Mosquito Larval Density and Their Habitat Physicochemical Characteristics in Mazandaran Province, northern Iran. 2017; : 1-19. 
